\title{
Appraisal of water quality and ecological sensitivity with reference to riverfront development along the River Gomti, India
}

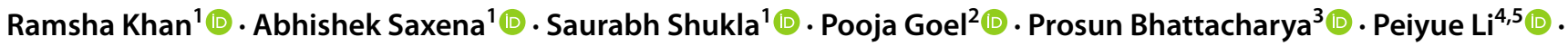 \\ Esmat F. Ali ${ }^{6}$. $\cdot$ Sabry M. Shaheen ${ }^{7,8,9}$
}

Received: 30 July 2021 / Accepted: 14 December 2021 / Published online: 5 January 2022

(c) The Author(s) 2022

\begin{abstract}
The conflict between the vitality of natural ecosystem versus artificially developed systems has existed since decades. The ecological sensitivity and socio-economic aspects associated with riverfront development along rivers have attracted the attention of environmentalists and ecologists across the globe. The present study evaluates the impacts of channelization and riverfront development on the water quality of river Gomti through Water Pollution Index (WPI) and other statistical tools. Of the total studied sites, 75\% were found to be in the 'highly polluted' category even after the development of riverfront. An approximate increase of $274.5 \%$ and $171.76 \%$ was witnessed in the WPI values at the midstream sites of Kudiaghat and Daliganj, respectively. This increase in the WPI values clearly stated the deteriorated water quality of river Gomti after the channelization. The major issue of domestic sewage discharge with partial or no treatment into the river seems to be unresolved even after a considerable period of riverfront development. This study can provide a reference database toward development of such projects across the globe.
\end{abstract}

Keywords Sewage $\cdot$ River restoration $\cdot$ Groundwater-fed $\cdot$ Lucknow city $\cdot$ River channelization

Abhishek Saxena

abhisheksaxena79@gmail.com

Saurabh Shukla

saurabh.shukla2020@gmail.com

Sabry M. Shaheen

shaheen@uni-wuppertal.de

Extended author information available on the last page of the article 


\section{Introduction}

The rehabilitative development of urban streams through riverfront construction is a globally employed methodology (Bockelmann et al. 2004; Che et al. 2012; Lu et al. 2019; Mitsch 2014; Thompson et al. 2018). The development of riverfront projects is transforming the freshwater ecosystems through alterations in water flow, fluvial habitat, floodplains, and water quality. The development of riverfront projects has attracted contradictory views with researchers emphasizing on the vitality of the natural state of rivers, while some arguing toward the need of artificial modifications. The lack of balance between channel engineering and ecological perspectives has created complexities for the river systems in the Ganga Basin, India (Dutta et al. 2018). The reduction in the density of fish population consequent to the destruction of potential natural habitats post-channelization has been mentioned in various studies (Blake and Rhanor 2020; Dutta et al. 2018; Jurajda 1995). The fragmentation of habitats into sub-clusters makes the survival of aquatic flora and fauna difficult (Jurajda 1995; Khan et al. 2014). The recolonization of such clusters due to the species sensitivity with respect to habitats has even caused extinction (Collinge 1998). The interdisciplinary understanding of ecology and channel engineering is very vital in such projects. The whole river system is very dynamic in nature; hence, development of a small part of the river further modifies the channel limiting the possibilities of restoration.

The River Gomti, a unique groundwater-fed river in the Ganga Alluvial Plain (GAP), is an important source for drinking water in many Indian cities and towns along the river basin (Shukla and Saxena 2020a, b, c, d). Residents in these cities, especially in Lucknow (capital of Uttar Pradesh), are exposed to various pollutants from the point and nonpoint sources including domestic sewage, industrial effluents, agricultural, and livestock waste which are complex to monitor, assess, and control (Khan et al. 2020; Tangri et al. 2018). The population of Lucknow city expanded by approximately $38 \%$ from 2001 to 2011, which had caused an excessive increase in the water demand for drinking purposes. The stress on the river is also highlighted by the fact that roughly $60 \%$ of the total water demand of 415 MLD (millions of liter per day) is fulfilled by river Gomti and remaining 170 MLD by subsurface water resources (Goel et al. 2018).

Hence, to augment towards the increasing demand and deteriorating water quality, the 'riverfront development' project for river Gomti was initiated in April 2015, which was completed in March 2017 in the Lucknow city. It included straightening, narrowing, and lining of the river channel, along with development of intercepting drains for efficient management of sewage. The beautification of the riverbank with parks was also included in the project.

Very limited studies discuss the impact of riverfront development and channelization on the water quality of the river Gomti. A study by Dutta et al. (2018) explained the need of maintaining environmental flows, ecological balance, and changes in water quality after the riverfront development. However, the study was more focused on morphological aspects of the riverfront development project, and no comparisons were made for water quality during preand post-channelization. Thus, the present study assesses the detailed impact of riverfront development on water quality of the river pre- and post-channelization. Because the riverfront development does not cover the entire stretch in the city of Lucknow, the present study discusses the water quality along various stretches of the river. An upstream site located at $\sim 30 \mathrm{~km}$ from Lucknow city was also selected to present a comparative view of the river water quality, at sites with and without riverfront development. The primary aim of this study was to assess the water quality of river Gomti in both the pre- and post-riverfront development phases. Various pollution zones are also identified through Q-mode hierarchical cluster analysis and represented through spatial maps. Finally, the source and inter-dependability of various water quality parameters were also assessed through Pearson's correlation analysis.

\section{Materials and methods}

\section{Study area}

The Gomti River Basin (GRB) exists between the $80^{\circ} 00^{\prime}-83^{\circ} 10^{\prime} \mathrm{E}$ longitude and $24^{\circ} 40^{\prime}-28^{\circ} 40^{\prime} \mathrm{N}$ latitude (Khan et al. 2021a, b, c). It forms the northwest part of the Indo-Gangetic alluvial plain having a catchment area of $30,437 \mathrm{~km}^{2}$. The GRB is categorized by two primary geologic units of Quaternary age (younger and older alluvium). The younger alluvial plain stretches along the river Gomti and forms a wide flood plain which supports agricultural activities throughout its stretch. The older alluvium occurs at higher elevation and is characterized by alluvial deposits comprising sand, clay, and kankar. The channel sediments of the river consist of quartz, feldspar, rock fragments, mica, and illite (major clay mineral). The origin of river Gomti is from 'Fulhar Jheel' at Madhotanda in Uttar Pradesh, and it meets the river Ganga after meandering through an approximate stretch of $960 \mathrm{~km}$. It has two major tributaries, i.e., the Saryu and Sai rivers, which join the river in Mohamadi and Jaunpur, respectively.

River Gomti divides the city of Lucknow, into two parts (cis and trans), and water from the river is lifted at Aishbagh waterworks for water supply in the city. The climate 
Fig. 1 Location map of sampling sites and River Gomti in Lucknow city, Uttar Pradesh

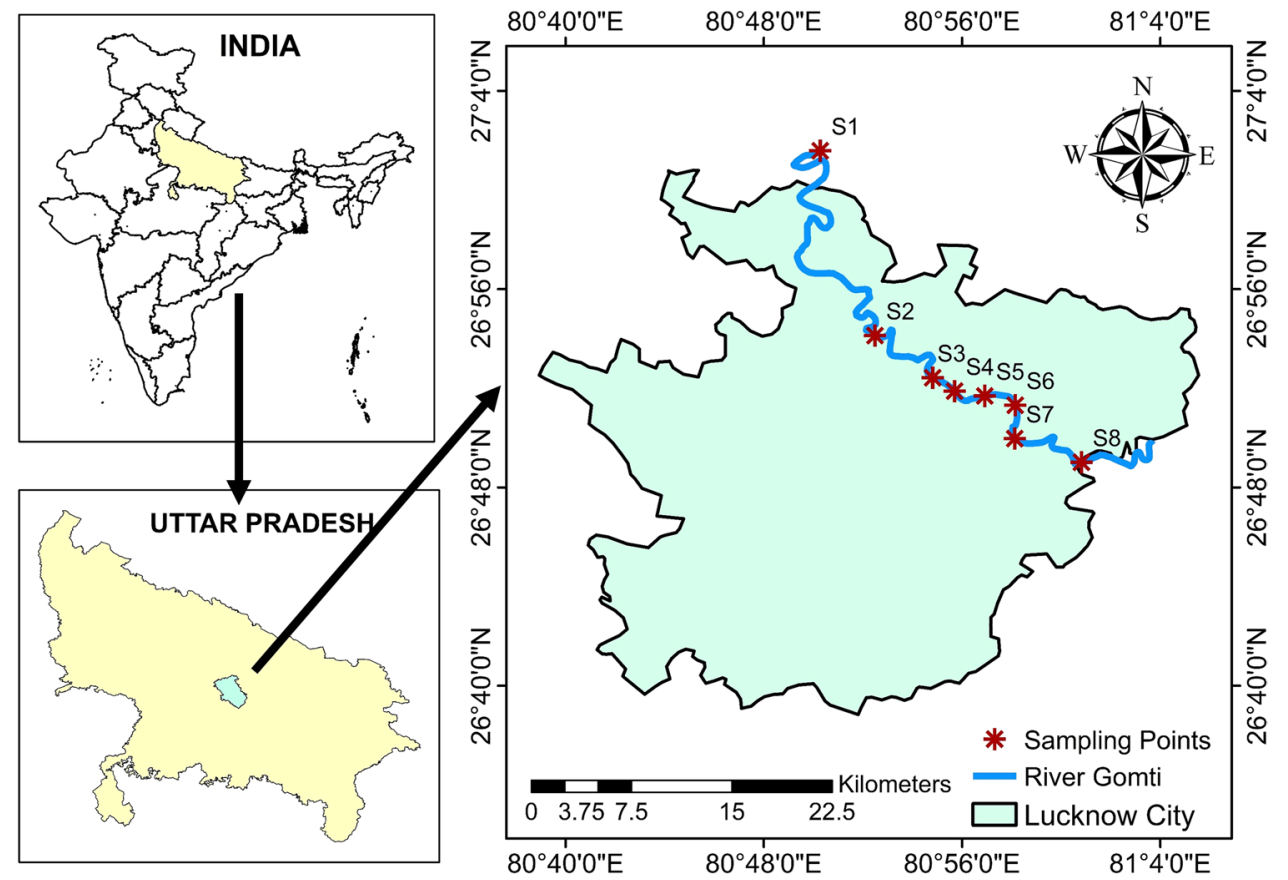

of Lucknow city varies between semiarid to subtropical monsoon type with a mean annual rainfall of $963 \mathrm{~mm}$ (Goel et al. 2018). The river flows from N-W direction toward S-E direction across the city. The river water is a major drinking water source and also fulfills requirements of industrial and agricultural sectors in Lucknow city. However, increasing population and water demand have contributed towards the deterioration of river water. Furthermore, the untreated domestic and industrial wastewater is released through 26 major drains causing a further decline in the water quality (Khan et al. 2021c). The riverfront development project has potentially been unable to tap these drains and still a large quantity of untreated wastewater is released into the river, which poses human health risks and endangers the aquatic population in the river as well.

\section{Sample collection and analysis}

Twenty-four water samples have been collected from river Gomti across the study area, with three samples from each location (one at each bank, and one from the center of the river). The present study is in continuation with the research conducted by Goel et al. (2018) in the year 2015 (before riverfront development), to evaluate the current status and impacts of riverfront development project on river Gomti. The sampling was done in the post-monsoon period of year 2019 at sites S1 (Chandrika Devi), S2 (IIM Road), S3 (Kudiaghat), S4 (Daliganj), S5 (Lakshman Mela), S6 (Bhaisakund), S7 (Dilkusha), S8 (Shahid Path) (Fig. 1). The channelization of the riverbanks starts from S3 at one of its banks, and from S5, it continues at both the banks of the river. The water samples were analyzed for $\mathrm{pH}$, dissolved oxygen (DO), biological oxygen demand (BOD), total coliform (TC), potassium $\left(\mathrm{K}^{+}\right)$, calcium $\left(\mathrm{Ca}^{2+}\right)$, phosphate $\left(\mathrm{PO}_{4}{ }^{2-}\right)$, nitrate $\left(\mathrm{NO}_{3}{ }^{-}\right)$, and fluoride $\left(\mathrm{F}^{-}\right)$to compute the WPI. The water samples were analyzed in accordance with the standard methods of APHA (2012). The water quality parameters $\mathrm{pH}$ and $\mathrm{DO}$ were measured at the site using potable $\mathrm{pH}$ meter and digital DO Meter (Lab Junction, LJ-831), respectively. BOD was computed using the Winkler's method in the laboratory, while $\mathrm{NO}_{3}{ }^{-}$and $\mathrm{F}^{-}$were analyzed using advanced research grade benchtop ion selective electrode (Hanna, $\mathrm{HI} 5522) . \mathrm{K}^{+}, \mathrm{Ca}^{2+}$, and $\mathrm{PO}_{4}{ }^{2-}$ were measured using ion chromatography (Metrohm 850).

\section{Quality assurance of results}

Analytical grade chemicals (purity $>97 \%$, from SigmaAldrich) were used for complete analytical procedures, to maintain the quality control and assurance (QA/QC) standards. Further, all the glasswares were soaked for one hour in diluted nitric acid (a 1\% nitric acid solution) and subsequently rinsed with distilled water. To remove the analytical inaccuracy, duplicate samples were collected and analyzed for each sampling location. The water samples were analyzed using calibrated equipment with acceptable uncertainties. An internal quality assurance system is applied regularly at the laboratory. During analyses, different concentrations of standard solutions were measured as an internal quality control. The relative standard deviation (RSD) values were less than 5\%. 


\section{Water pollution index}

Water quality is a quantification parameter for the nature of water concerning the anthropogenic requirements (Bempah and Ewusi 2016; Shukla and Saxena 2020a). Water quality assessment is primarily done using various physical, chemical, and biological parameters (Shukla and Saxena 2020b). The evaluation of the status of water pollution of rivers is a critical and emerging area of interest around the world, requiring data collection, assessment, and interpretation (Shukla et al. 2020c). There have been many approaches for assessing the overall water quality (Gorgij et al. 2019; He and Wu 2019; He et al. 2019; Li et al. 2018; Su et al. 2019, 2020; Tian and Wu 2019). The efficacy of WPI is higher in comparison with that of conventional indexing methodologies. The use of varying weights and theoretical ideal value of any parameter can possibly affect the water quality indexing approach. The unsegregated approach of WPI is more accurate considering the conversion of input variables to a single index value. Hence, the slightest variation in the input parameter concentration can affect the WPI category of water quality.

In the current study, nine water quality parameters including $\mathrm{pH}, \mathrm{DO}, \mathrm{BOD}$, Total Coliform, $\mathrm{F}^{-}, \mathrm{Ca}^{2+}, \mathrm{K}^{+}$, $\mathrm{NO}_{3}{ }^{-}, \mathrm{PO}_{4}{ }^{3-}$ were selected for pollution load computation. The number of water quality parameters $n$ can vary considering the flexible approach adopted in the WPI methodology.

The first step in pollution load computation (PLi) of $i^{\text {th }}$ parameter is done using equation below:

$\mathrm{PLi}=1+\frac{\mathrm{Ci}-\mathrm{Si}}{\mathrm{Si}}$

where $\mathrm{Ci}$ is the observed concentration, and $\mathrm{Si}$ is the standard or highest permissible limit for the respective parameter. The equation for PLi computation is different for various $\mathrm{pH}$ values, i.e., $\mathrm{pH}$ value 7 is considered as neutral, but $<7$ or $>7 \mathrm{pH}$ values are supposedly detrimental. With this view following equations are recommended for different $\mathrm{pH}$ ranges:

If $\mathrm{pH}$ value is $<7$, then Eq. 1.1 is recommended where $\mathrm{Si}_{\mathrm{a}}$ is the minimum acceptable $\mathrm{pH}$ value, i.e., 6.5, and Eq. 1.1 is used:

$\mathrm{PLi}=\frac{\mathrm{Ci}-7}{\mathrm{Si}_{\mathrm{a}}-7}$

If $\mathrm{pH}$ is $>7$, then $\mathrm{Si}_{\mathrm{b}}$ is the maximum acceptable $\mathrm{pH}$ value, i.e., 8.5, and Eq. 1.2 is used:

$\mathrm{PLi}=\frac{\mathrm{Ci}-7}{\mathrm{Si}_{\mathrm{b}}-7}$
Finally, the pollution status of a water sample or water pollution index (WPI) with n number of variables is calculated through aggregation of PLi values and finally dividing with $\mathrm{n}$, Eq. 1.3 is used.

$\mathrm{WPI}=\frac{1}{\mathrm{n}} \sum_{\mathrm{i}=1}^{\mathrm{n}} \mathrm{PLi}$

\section{Statistical analysis}

The temporal/seasonal variation in the dataset from pre-riverfront development to the dataset in post-riverfront development was evaluated with the nonparametric Mann-Whitney $U$ test (Woldeab et al. 2018). The spatial variation in water quality parameters among different sampling sites was evaluated with the Kruskal-Wallis $H$ test (Fatema et al. 2014). Furthermore, Pearson's correlation matrix and hierarchical cluster analysis (HCA) were performed using OriginPro 2020b software package (OriginLab Corporation, Northampton, USA).

Two correlation matrices were generated, each for the dataset from 2015 to 2019, respectively. The Pearson's correlation analysis is a widely used tool which estimates the linear dependence between various parameters (Batabyal and Chakraborty 2015; Khan et al. 2021b; Wu et al. 2014, 2020; Li et al. 2019; Ren et al. 2021). The value of Pearson's correlation coefficient, ' $r$,' lies between \pm 1 , suggesting the positive or negative correlation, and there is no correlation between the parameters when ' $r$ ' is zero. Moreover, when ' $r$ ' lies between \pm 0.9 and \pm 1 , a 'very strong' correlation exists between the parameters. Similarly, a 'strong' correlation exists if values of ' $r$ ' vary between \pm 0.76 and \pm 0.89 , a 'good' correlation is there when the values of ' $r$ ' lie in the range of 0.51 to \pm 0.75 , and the correlation is called 'poor' for ' $r$ ' values of 0 to \pm 0.50 (Batabyal and Chakraborty 2015).

The datasets of water quality parameters from the 2015 to 2019 were further subjected to Q-mode HCA (Q-HCA). HCA uses either similarities or dissimilarities between the parameters within the datasets and classifies the dataset into several clusters according to the distance of similarity/ dissimilarity between these clusters (Adimalla et al. 2020; Elumalai et al. 2020; Loh et al. 2020; Shukla and Saxena 2020d). Q-HCA helps in classification of the monitoring sites based on their similar chemical composition geochemistry, which suggests a probable origin of contaminants (Zhu et al. 2017). For Q-HCA, the Ward's method with squared Euclidian distances was used, which is considered to provide the best results. 
Fig. 2 Variation of WQI in preriverfront and post-riverfront development

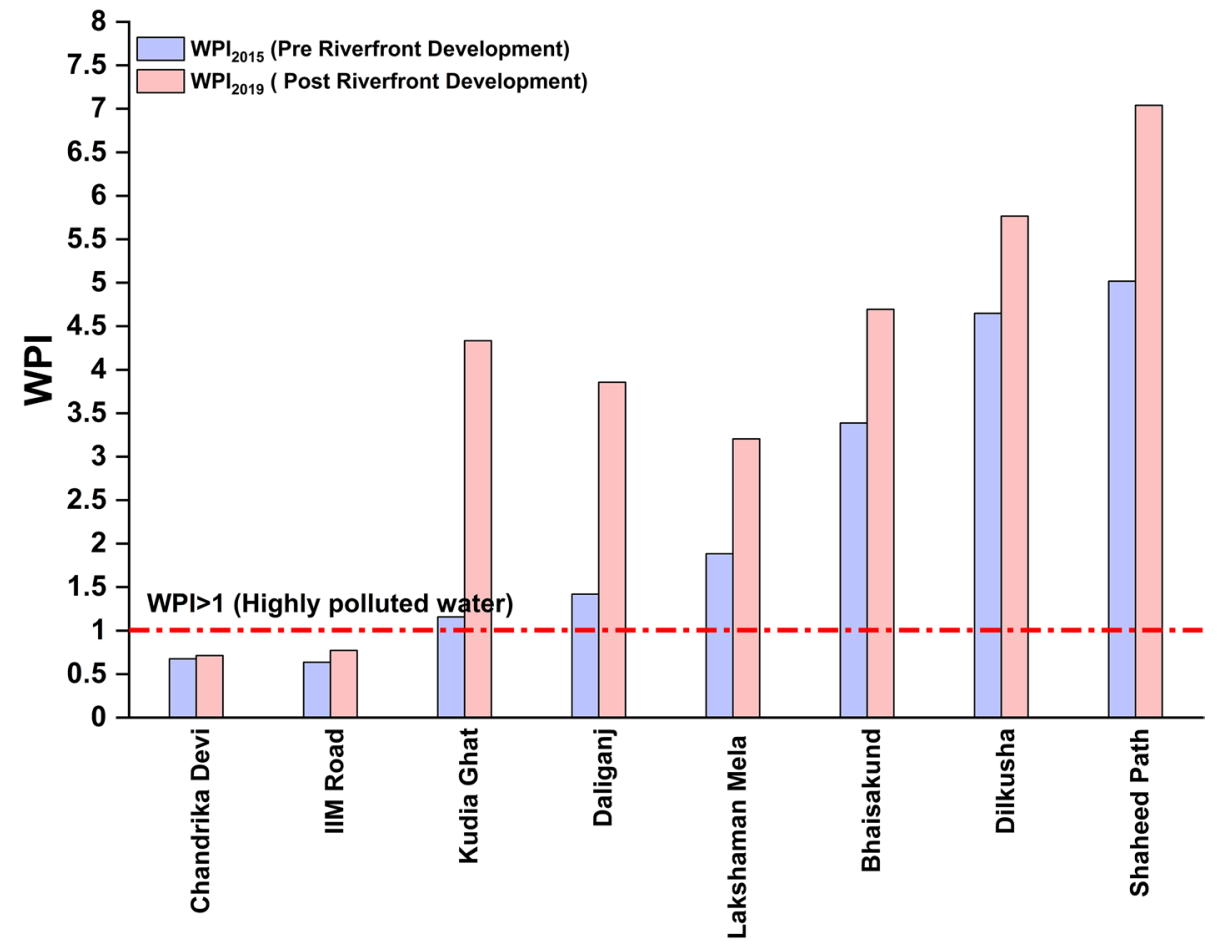

\section{Results and discussion}

\section{Variation in water pollution index post-channelization}

The study by Goel et al. (2018) highlighted the impact of untreated domestic sewage discharged in the river and discussed the possible inefficiency of sewerage systems, suggesting possible remediation measures. The riverfront development project included straightening and shortening of river channel, affecting its width, shape, and riverbed, and comprising the construction of a diaphragm wall on both banks along a stretch of $\sim 8 \mathrm{~km}$ (Dutta et al. 2018).

The water samples at all sites fell in the 'highly polluted' category during both pre- and post-channelization surveys. The increased WPI values after riverfront development clearly stated the deteriorated water quality of the river. A very steep increase in the WPI values in the post-riverfront development phase was witnessed at all sites in the order S3 $>\mathrm{S} 4>\mathrm{S} 5>\mathrm{S} 8>\mathrm{S} 6>\mathrm{S} 7>\mathrm{S} 2>\mathrm{S} 1$ as illustrated in Fig. 2. The presence of only one water sample in the 'good' category water quality after the development of the Gomti riverfront was seen in the study. The highest deterioration in the water quality was seen at site S3 $(\sim 275 \%)$ signifying the possible influence of small-scale local manufacturing units, dyeing of textile, washing clothes, etc., in the vicinity. The water quality at site S4 showed a significant deterioration, and WPI value increased by $\sim 172 \%$, signifying the direct discharge of untreated domestic sewage into the river. The
WPI values at sites S5 and S6 showed an increase of 70.1\% and $\sim 38.6 \%$, respectively. Various cremation-related rituals performed in the vicinity of both sites and consequent anthropogenic influence emerge as possible causes of deteriorated water quality. The WPI of the water sample at site S7 showed an approximate increase of $24.03 \%$ after the channelization. The WPI value at downstream site S8 increased by $40.26 \%$ after the channelization. The upstream site S1 located $\sim 30 \mathrm{~km}$ from the city and is not channelized, and it showed the minimum increase in the WPI value $(\sim 5.76 \%)$. The WPI value at this site was 0.71 which felt in the 'good' water quality category.

\section{Cluster analysis}

For a better representation and understanding of the impacts of channelization, a stretchwise assessment was required. Hence, the variation in water quality parameters is assessed as per the various clusters obtained through Q-HCA. The stretchwise summary of various water quality parameters and their statistical measures is presented in Table 1. The results of Q-HCA were also plotted as dendrograms for both assessment periods (pre- and post-channelization). The dendrograms present the extent of similarities between various sampling locations, and similar sites are kept in same cluster. The sampling locations were categorized grouped into two clusters for pre-channelization period (Fig. 3a) and three clusters for post-channelization period of assessment (Fig. 3b). For the pre-riverfront development period, Cluster

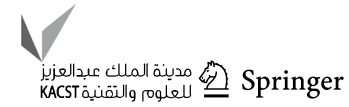


Table 1 Descriptive statistics for clusters obtained through Q-HCA

\begin{tabular}{|c|c|c|c|c|c|c|c|c|c|c|}
\hline Statistics & $\mathrm{pH}$ & $\begin{array}{l}\text { DO } \\
\mathrm{mg} / 1\end{array}$ & $\begin{array}{l}\text { BOD } \\
\mathrm{mg} / 1\end{array}$ & $\begin{array}{l}\text { TC } \\
\text { MPN/100 ml }\end{array}$ & $\begin{array}{l}\mathrm{EC} \\
\mathrm{mS} / \mathrm{cm}\end{array}$ & $\begin{array}{l}\mathrm{NO}_{3}^{-} \\
\mathrm{mg} / 1\end{array}$ & $\begin{array}{l}\mathrm{PO}_{4}^{2-} \\
\mathrm{mg} / 1\end{array}$ & $\begin{array}{l}\mathrm{F}^{-} \\
\mathrm{mg} / \mathrm{l}\end{array}$ & $\begin{array}{l}\mathrm{K}^{+} \\
\mathrm{mg} / \mathrm{l}\end{array}$ & $\begin{array}{l}\mathrm{Ca}^{2+} \\
\mathrm{mg} / \mathrm{l}\end{array}$ \\
\hline \multicolumn{11}{|c|}{ January 2015} \\
\hline \multicolumn{11}{|c|}{ Cluster I } \\
\hline Min & 6.90 & 1.00 & 8.50 & $94,000.00$ & 0.70 & 1.68 & 0.63 & 0.45 & 6.09 & 23.34 \\
\hline $\operatorname{Max}$ & 6.95 & 2.20 & 12.00 & $130,000.00$ & 1.28 & 3.10 & 1.39 & 0.52 & 8.10 & 26.00 \\
\hline Mean & 6.92 & 1.57 & 10.00 & $111,333.33$ & 1.03 & 2.35 & 1.07 & 0.48 & 7.16 & 24.82 \\
\hline SD & 0.03 & 0.60 & 1.80 & $18,037.00$ & 0.30 & 0.71 & 0.40 & 0.04 & 1.01 & 1.35 \\
\hline \multicolumn{11}{|l|}{ Cluster II } \\
\hline Min & 7.09 & 3.70 & 2.80 & 1700.00 & 0.40 & 0.85 & 0.05 & 0.41 & 4.57 & 10.86 \\
\hline $\operatorname{Max}$ & 8.35 & 11.00 & 6.50 & $49,000.00$ & 0.95 & 2.48 & 0.55 & 0.49 & 6.48 & 23.24 \\
\hline Mean & 7.66 & 7.94 & 4.24 & $14,900.00$ & 0.64 & 1.79 & 0.29 & 0.45 & 5.57 & 19.54 \\
\hline SD & 0.61 & 3.37 & 1.51 & $19,904.52$ & 0.21 & 0.76 & 0.22 & 0.03 & 0.91 & 5.19 \\
\hline \multicolumn{11}{|c|}{ October 2019} \\
\hline \multicolumn{11}{|c|}{ Cluster I } \\
\hline- & 7.70 & 1.40 & 16.00 & $200,000.00$ & 0.46 & 3.90 & 1.31 & 1.60 & 8.61 & 27.11 \\
\hline \multicolumn{11}{|l|}{ Cluster II } \\
\hline Min & 7.60 & 1.70 & 11.10 & $90,000.00$ & 0.38 & 1.80 & 0.28 & 0.85 & 6.21 & 23.65 \\
\hline Max & 7.80 & 3.90 & 13.00 & $140,000.00$ & 0.45 & 3.30 & 1.52 & 1.90 & 7.71 & 26.31 \\
\hline Mean & 7.70 & 2.84 & 12.08 & $119,000.00$ & 0.41 & 2.68 & 0.73 & 1.31 & 6.77 & 24.64 \\
\hline SD & 0.10 & 0.98 & 0.83 & $22,472.21$ & 0.03 & 0.65 & 0.47 & 0.39 & 0.58 & 1.01 \\
\hline \multicolumn{11}{|c|}{ Cluster III } \\
\hline Min & 8.00 & 5.60 & 2.90 & 6000.00 & 0.37 & 1.85 & 0.06 & 0.54 & 4.88 & 11.51 \\
\hline Max & 8.20 & 5.90 & 3.60 & $11,000.00$ & 0.42 & 2.10 & 0.13 & 0.80 & 4.92 & 19.71 \\
\hline Mean & 8.10 & 5.75 & 3.25 & 8500.00 & 0.39 & 1.98 & 0.10 & 0.67 & 4.90 & 15.61 \\
\hline SD & 0.14 & 0.21 & 0.49 & 3535.53 & 0.04 & 0.18 & 0.05 & 0.18 & 0.03 & 5.80 \\
\hline
\end{tabular}

Min.: minimum, Max.: maximum, $S D$ standard deviation
I had three sites, viz. Bhaisakund (S6), Dilkusha (S7), and Shaheed Path (S8), having similar values of all the parameters. Cluster I can be considered as 'very high' pollution zone based on the mean values of water quality parameters, especially TC (Table 1). Similarly, cluster II grouped five sites, Chandrika Devi (S1), IIM Road (S2), Kudia Ghat (S3), Daliganj (S4), and Lakshman Mela (S5), because of similarities between their values of $\mathrm{BOD}, \mathrm{EC}, \mathrm{NO}_{3}^{-}, \mathrm{K}^{+}$, and $\mathrm{F}^{-}$, were the reason behind grouping of these sites into a cluster. Cluster II can be considered as 'low pollution' zone based on the mean values of the water quality parameters (Table 1 ).

In the post-riverfront development period, cluster I had only one site, viz. Shaheed Path (S8), which was the most polluted site across the whole stretch considered in this study, with maximum values of all the parameters reported at this location (Fig. 3b). Cluster II had two sub-clusters, with Daliganj (S4) and Lakshman Mela (S5) in one group, and Kudia Ghat (S3), Bhaisakund (S6), and Dilkusha (S7) in another group. Cluster II can be categorized as representing 'moderate to high pollution' and has similar values of the water quality parameters at all sites. Further, cluster III can be categorized as the least polluted zone, having Chandrika
Devi (S1) and IIM Road (S2) grouped together. Based on the results of stretchwise cluster analysis, it can be concluded that riverfront had a critical deteriorating impact on the water quality parameters. Sites S3, S4, and S5, which were in the low pollution zone in the pre-channelization period, were found to be in 'moderate to high pollution' zone after the channelization.

\section{Pearson's correlation matrix}

The significance of spatial and temporal differences between water quality parameters was verified using the Kruskal-Wallis $H$ test and the Mann-Whitney $U$ test, respectively, with respect to the temporal variation between the dataset from pre- and post-riverfront development, and the Mann-Whitney $U$ tests indicated that the distribution cannot be considered as significantly different at the significance level of 0.05. Moreover, the Kruskal-Wallis $H$ test indicated that the water quality parameters were significantly different among the sampling sites with $p<0.05$ and a Chi-square value of $\sim 70$. It can be concluded from these results that various 
Fig. 3 Dendrograms for Q-mode hierarchical cluster analysis (Q-HCA) for the dataset from a pre-riverfront development and $\mathbf{b}$ post-riverfront development
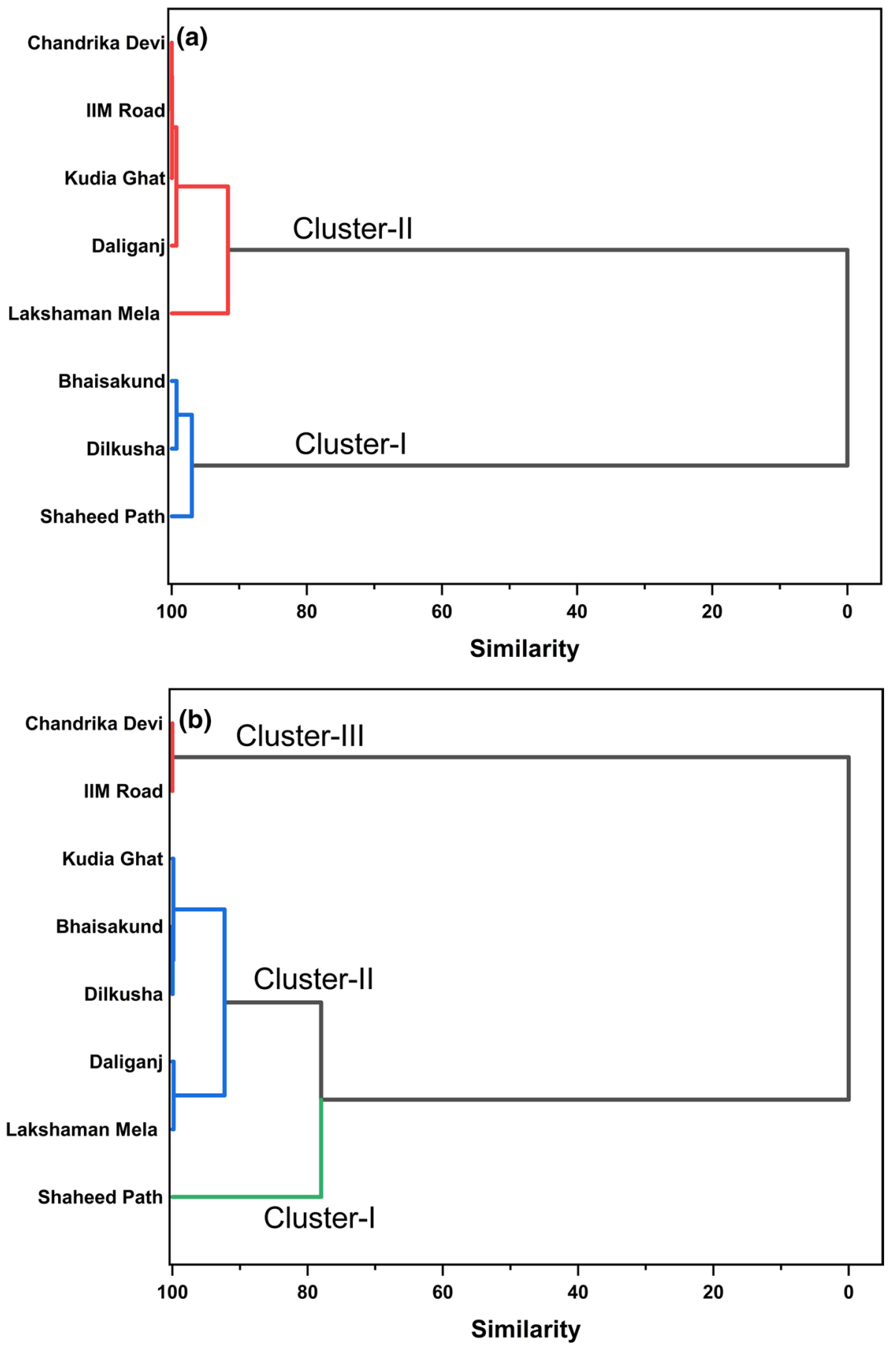

anthropogenic activities can be attributed behind the variation among the water quality parameters from pre- to post-channelization.

Further, the correlation matrices for the water quality parameters are presented in Fig. 4a, b. It can be seen that $\mathrm{pH}$ was negatively correlated with all parameters except DO in both sampling periods. Similarly, DO had a 'very strong' negative correlation with BOD and TC pre- and post-riverfront development, whereas BOD and TC were very strongly positively correlated, suggesting that sewage is the primary source of pollution in River Gomti. All the cations had 'good' to 'very strong' correlation with EC, suggesting that variation of EC is controlled by these ions in the River Gomti. Nitrate exhibited a 'strong' 


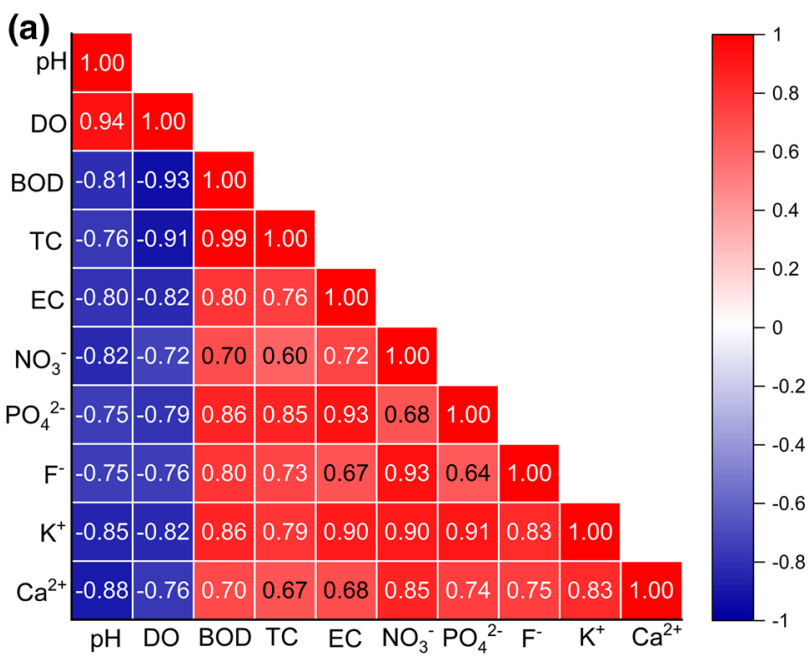

(b)

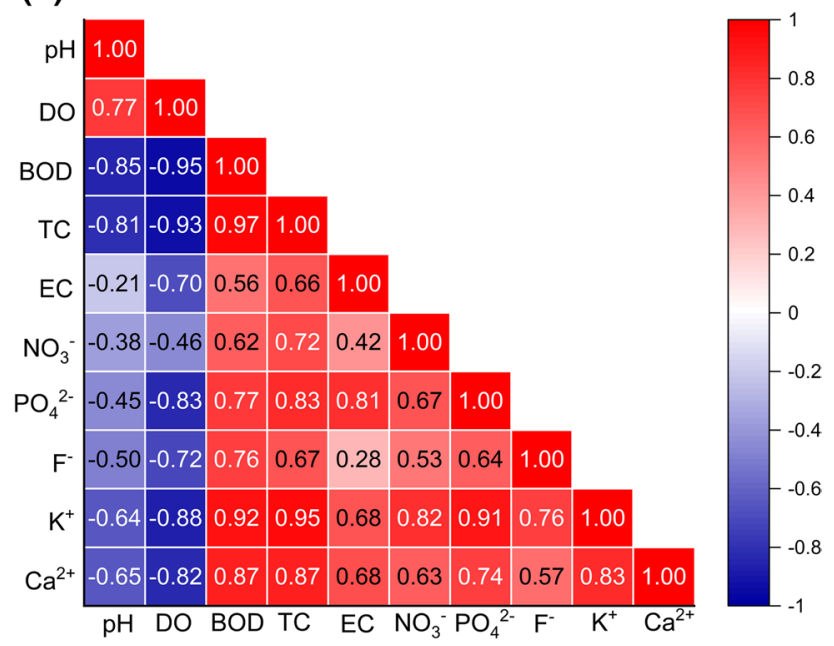

Fig. 4 Pearson's correlation matrix for a January 2015 and b October 2019 representing the dependence of water quality parameters

correlation with $\mathrm{K}^{+}$in both sampling periods, suggesting that contribution from agricultural practices and subsequent runoff can be responsible for the occurrence of these ions in the river water. Moreover, $\mathrm{Ca}^{2+}$ and $\mathrm{F}^{-}$also had a 'strong' correlation with $\mathrm{K}^{+}$, suggesting common anthropogenic origin of these contaminants.

\section{Spatial distribution of WPI}

The spatial variation of WPI across different stretches of River Gomti in Lucknow city was determined through inverse distance weighted (IDW) interpolation using ArcMap 10.3. The WPI variation along the river clearly indicated the increasing pollution load and depleting water quality as illustrated in Fig. 5. The minimum pollution was witnessed at sites $\mathrm{S} 1$ and $\mathrm{S} 2$ with water sample showing WPI values 0.71 (good water quality) and 0.77 (moderately

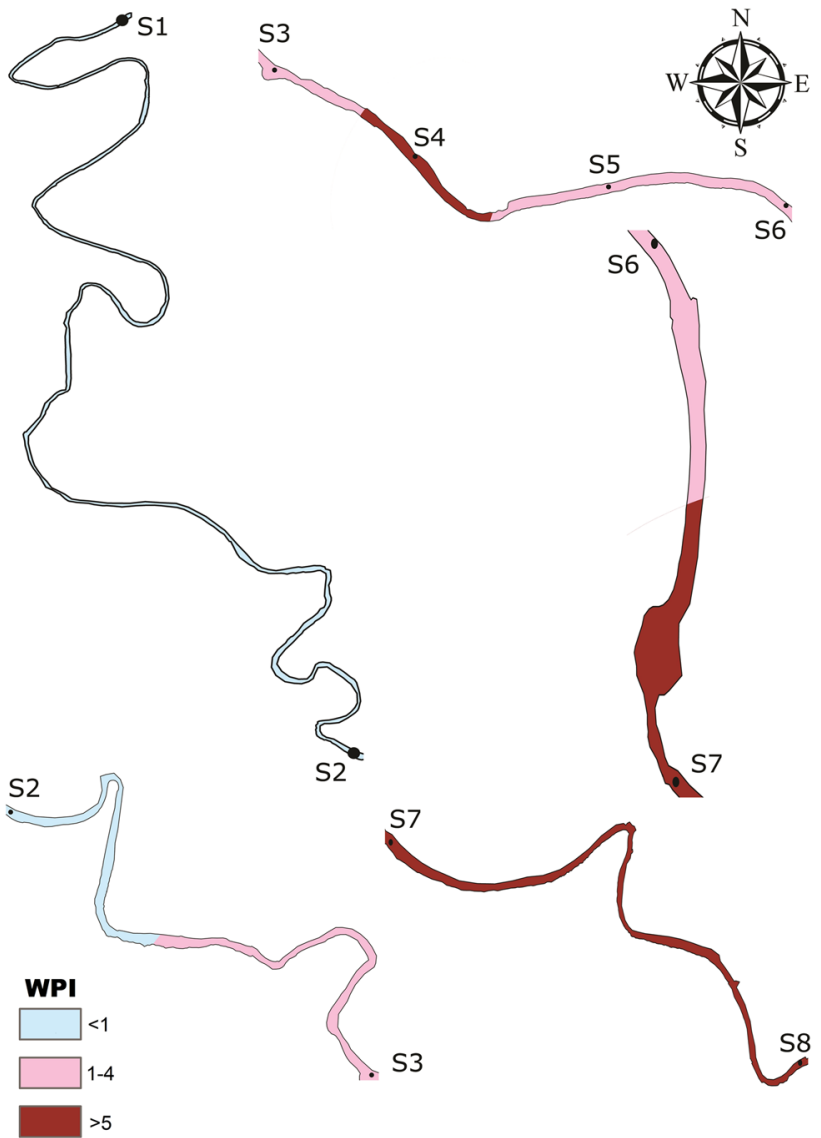

Fig. 5 Spatial variation of WQI in various stretches of River Gomti

polluted quality), respectively. The upstream location of the sites emerged as the primary reason for better water quality. This finding was in coherence with the results from cluster analysis in which site S1 and S2 occurred in the least polluted zone, i.e., Cluster III (Fig. 3b). The midstream sites (S3, S4, S5, and S6) showed "highly polluted" water quality which was again in coherence with their grouping in Cluster II by the Q-HCA. Sites S7 and S8 had the worst water quality with maximum pollution load. The downstream location of the sites and sluggish flow of river water because of the development of riverfront prominently affects the water quality of sites S7 and S8. The placement of site S8 in Cluster I confirms our findings from the values of WPI. Thus, it can be clearly seen that the water quality at all sites throughout the stretch after the riverfront development has not witnessed any improvement. The potential causes of deteriorating water quality include the reduced flow in the river caused due to shortening of the river channel and a reduction in channel width through the construction of a diaphragm wall along both banks in a stretch $\sim 8 \mathrm{~km}$. The lining of the riverbank has minimized the possibility of adsorption of pollutants on sediments. The extensive development of riverfront infrastructure, including weirs and dams, has 
caused disruption to the natural river habitats. The reducing aquatic population because of the disruption of natural riffle-pool sequences, and excessive dredging during construction have been highlighted in a previous study (Dutta et al. 2018). The reduction of fish biomass in river Gomti has been reported after channelization highlighting the negative impact of excessive dredging and disturbing river banks. The reduced pace of reinstatement of fish population and even no recovery has been reported after channelization in various studies (Kennedy and Turner 2011; Sharan 2016; Vaughan and Ormerod 2010).

\section{Riverfront development and its impacts on river restoration}

Riverfront development and subsequent restoration projects across the globe aim at the maintenance and improvement of riverine ecosystem goods and services. But the maintenance of balance between environment, ecology, and channel engineering should be considered in such river restoration projects. The dominance of channelization engineering can cause major deterioration of the water quality of rivers, as seen in river Gomti. Modifications of ecology, floodplains, and other key fluvial characteristics as a result of channelization have been witnessed in the river Gomti (Goel et al. 2018). The channelization, covering floodplains with concrete, and filling of wetlands have contributed towards modification of habitats critically affecting the fish diversity. A huge-scale variation in the deposition of sediments in unpredictable ways can be witnessed at sites below channelized river sections (Kennedy and Turner 2011).

River Gomti supports various vegetation patches that perform the function of sustaining processes of channel erosion and deposition. The existence of pools and riffles is vital for the optimal survival of fishes, considering their use as areas for feeding, cover, and breeding. The tendency of pools to scour at high flow and fill at low flow and vice versa in riffles is very important in the maintenance of poolriffle sequence morphology. Such sequences, in turn, act as dwellings for some organisms, which consequently serve as food for other organisms (Keller 1978). The removal of pool-riffle sequences from the river Gomti has occurred as a result of the heavy channelization. The dredging action has led to degradation of natural habitats, remobilization of contaminants, increases in suspended sediment concentrations, and uneven sedimentation. Pool-riffle sequences are composed of various materials, which include inputs from benthonic species, including fishes (Jurajda 1995). The development of riverfront modification of channel width for river straightening led to the loss of natural habitats. The channelization of the river Gomti has also led to a scarcity of lentic zones and side arms with aquatic vegetation. The diaphragm wall across the stretch of River Gomti has removed some fish habitats considering the absence of required mild slope shorelines. The local fisherman, during an interaction at site visits (Fig. S1), expressed immense worry and trouble considering the reduction of the fish population. The role of in-stream habitats in the maintenance of heterogeneity of fish population is very vital. The absence of many primary fish habitats after the river channelization has also been reported (Dutta et al. 2018). The homogenization of various fish-fauna habitats at a regional scale can lead to a potential loss of future habitats causing depletion of fish diversity. The straightening and the reduction in width of the river have disrupted the natural state of the channel, modifying flow velocity, gradient, and depth of the river channel. The changed flow and constant release of untreated/ partially treated wastewater from various drains across the Lucknow city have directly affected the breeding and survival of aquatic flora and fauna populations. These changes have consequently led to a reduction in the fish population. A report by Ahmad (2013) had also mentioned about the need to strictly avoid reducing the width of the river channel $(<250 \mathrm{~m})$ during the riverfront development and channelization project. However, the design of diaphragm walls seems to lack a coherent approach toward incorporating the suggestions and providing to the maintenance of river ecology. The balance between river ecology and channel development was vital in this riverfront development project, which seems not to have been maintained.

\section{Conclusions}

Riverfronts can prove to be a rare resource toward urban development and eco-environmental protection when developed with ecological sensitivity. However, in case of river Gomti the aim towards development of water-land and human-nature interaction zone could not be attained with complete efficacy. An average increase of $\sim 81 \%$ in the WPI values across all the sites post-riverfront development was assessed in the study. This increase stated the deteriorated river water quality highlighting the unstopped discharge of sewage with partial or no treatment, raising concerns toward the operation and management of sewerage systems. The lowest water quality was witnessed at the downstream site of Shaheed Path with a WPI value of '7.04.' The lowest depletion in the water quality $(0.71 \%$ and $0.77 \%)$ was witnessed at the two upstream sites (S1 and S2) which are notably not channelized. The artificial modification through straightening and decrease in the width of the river channel have affected the natural flow along with the associated selfcleaning capacity of River Gomti. Thus, the current study highlights the need of a balanced and coherent approach with ecologists, environmentalists, and civil engineers working together considering all aspects associated with 
the impacts of riverfront development on the natural state of surface water resources.

Supplementary Information The online version contains supplementary material available at https://doi.org/10.1007/s13201-021-01560-9.

Acknowledgements Authors are thankful to (Prof.) Dr. A. K. Singh, Vice-Chancellor, Shri Ramswaroop Memorial University, for his support during this study. The authors would also like to acknowledge the support from Dr. D. K. Saxena, Bareilly College. The Seventh author (EFA) is also thankful to Taif University Researchers Supporting Project Number (TURSP-2020/65), Taif University, Saudi Arabia, for the financial support and research facilities.

Funding The author(s) received no specific funding for this work.

Availability of data and materials Data will be made available on request.

\section{Declarations}

Conflict of interest The authors declare no competing interests.

Consent for publication Not applicable.

Ethics approval and consent to participate Not applicable.

Open Access This article is licensed under a Creative Commons Attribution 4.0 International License, which permits use, sharing, adaptation, distribution and reproduction in any medium or format, as long as you give appropriate credit to the original author(s) and the source, provide a link to the Creative Commons licence, and indicate if changes were made. The images or other third party material in this article are included in the article's Creative Commons licence, unless indicated otherwise in a credit line to the material. If material is not included in the article's Creative Commons licence and your intended use is not permitted by statutory regulation or exceeds the permitted use, you will need to obtain permission directly from the copyright holder. To view a copy of this licence, visit http://creativecommons.org/licenses/by/4.0/.

\section{References}

Adimalla N, Qian H, Li P (2020) Entropy water quality index and probabilistic health risk assessment from geochemistry of groundwaters in hard rock terrain of Nanganur County, South India. Geochemistry 80:125544. https://doi.org/10.1016/j.chemer.2019. 125544

Ahmad Z (2013) Hydrological study for Gomti river front development prepared for Lucknow Development Authority. Department of Civil Engineering, Indian Institute ofTechnology,Roorkee.https:// ddmtn57ju2md7.cloudfront.net/media/bbifiles/1181924/38eeafb5ca82-4c74-8c64-65170953eb36.pdf. Accessed 24 Febr 2021

APHA (2012) Standard Methods for the Examination of Water and Wastewater, twenty second ed. American Public Health Association, Washington, DC. Accessed 24 Febr 2021

Batabyal AK, Chakraborty S (2015) Hydrogeochemistry and water quality index in the assessment of groundwater quality for drinking uses. Water Environ Res 87:607-617. https://doi.org/10.2175/ $106143015 \times 14212658613956$
Bempah CK, Ewusi A (2016) Heavy metals contamination and human health risk assessment around Obuasi gold mine in Ghana. Environ Monit Assess 188(5):261. https://doi.org/10.1007/ s10661-016-5241-3

Blake C, Rhanor AK (2020) The impact of channelization on macroinvertebrate bioindicators in small order Illinois streams: insights from long-term citizen science research. Aquat Sci 82:1-11. https://doi.org/10.1007/s00027-020-0706-4

Bockelmann BN, Fenrich EK, Lin B, Falconer RA (2004) Development of an ecohydraulics model for stream and river restoration. Ecol Eng 22:227-235. https://doi.org/10.1016/j.ecoleng.2004.04.003

Che Y, Yang K, Chen T, Xu Q (2012) Assessing a riverfront rehabilitation project using the comprehensive index of public accessibility. Ecol Eng 40:80-87. https://doi.org/10.1016/j.ecoleng.2011.12.008

Collinge SK (1998) Spatial arrangement of habitat patches and corridors: clues from ecological field experiments. Landsc Urban Plan 42:157-168. https://doi.org/10.1016/S0169-2046(98)00085-1

Das B, Jain S, Singh S, Thakur P (2019) Evaluation of multisite performance of SWAT model in the Gomti River Basin, India. Appl Water Sci 9:3. https://doi.org/10.1007/s13201-019-1013-x

Dutta V, Sharma U, Iqbal K, Adeeba Kumar R, Pathak AK (2018) Impact of river channelization and riverfront development on fluvial habitat: evidence from Gomti River, a tributary of Ganges, India. Environ Sustain 1:167-184. https://doi.org/10.1007/ s42398-018-0016-0

Elumalai V, Nethononda VG, Manivannan V, Rajmohan N, Li P, Elango L (2020) Groundwater quality assessment and application of multivariate statistical analysis in Luvuvhu catchment, Limpopo, South Africa. J Afr Earth Sci 171:103967. https://doi. org/10.1016/j.jafrearsci.2020.103967

Ewaid SH, Abed SA (2017) Water quality index for Al-Gharraf River, southern Iraq. Egypt J Aquat Res 43:117-122. https://doi.org/10. 1016/j.ejar.2017.03.001

Fatema K, Wan Maznah WO, Isa MM (2014) Spatial and temporal variation of physico-chemical parameters in the merbok estuary, Kedah, Malaysia. Trop Life Sci Res 25(2):1-19. https://doi.org/ 10.1007/s10661-015-4354-4

Goel P, Saxena A, Singh DS, Verma D (2018) Impact of rapid urbanization on water quality index in groundwater fed Gomati River, Lucknow, India. Curr Sci 114:650-654. https://doi.org/10.18520/ cs/v114/i03/650-654

Gorgij AD, Wu J, Moghadam AA (2019) Groundwater quality ranking using the improved entropy TOPSIS method: a case study in Azarshahr plain aquifer, east Azerbaijan. Iran Hum Ecol Risk Assess 25:176-190. https://doi.org/10.1080/10807039.2018.1564235

He S, Wu J (2019) Hydrogeochemical characteristics, groundwater quality, and health risks from hexavalent chromium and nitrate in groundwater of Huanhe formation in Wuqi County, Northwest China. Expo Health 11:125-137. https://doi.org/10.1007/ s12403-018-0289-7

He X, Wu J, He S (2019) Hydrochemical characteristics and quality evaluation of groundwater in terms of health risks in Luohe aquifer in Wuqi County of the Chinese Loess Plateau, northwest China. Hum Ecol Risk Assess 25:32-51. https://doi.org/10.1080/ 10807039.2018.1531693

Jurajda P (1995) Effect of channelization and regulation on fish recruitment in a flood plain river. Regul Rivers Res Manag 10:207-215. https://doi.org/10.1002/rrr.3450100215

Keller EA (1978) Pools, riffles, and channelization. Environ Geol 2:119-127. https://doi.org/10.1007/BF02380474

Kennedy TL, Turner TF (2011) River channelization reduces nutrient flow and macroinvertebrate diversity at the aquatic terrestrial transition zone. Ecosphere. https://doi.org/10.1890/ES11-00047.1

Khan MS, Dimri NK, Nawab A, Ilyas O, Gautam P (2014) Habitat use pattern and conservation status of smooth-coated otters Lutrogale 
perspicillata in the Upper Ganges Basin, India. Anim Biodivers Conserv 37:69-76. https://doi.org/10.32800/abc.2014.37.0069

Khan R, Saxena A, Shukla S (2020) Evaluation of heavy metal pollution for River Gomti, in parts of Ganga Alluvial Plain, India. SN Appl Sci 2:1451. https://doi.org/10.1007/s42452-020-03233-9

Khan R, Saxena A, Shukla S (2021a) Assessment of the impact of COVID-19 lockdown on the heavy metal pollution in the River Gomti, Lucknow city, Uttar Pradesh, India. Environ Qual Manag Tqem 1:21746. https://doi.org/10.1002/tqem.21746

Khan R, Saxena A, Shukla S, Sekar S, Goel P (2021b) Effect of COVID-19 lockdown on the water quality index of River Gomti, India, with potential hazard of faecal-oral transmission. Environ Sci Pollut Res 28:33021-33029

Khan R, Saxena A, Shukla S, Sekar S, Senapathi V, Wu J (2021c) Environmental contamination by heavy metals and associated human health risk assessment: a case study of surface water in Gomti River Basin, India. Environ Sci Pollut Res Int 28(40):5610556116. https://doi.org/10.1007/s11356-021-14592-0

Li P, He S, He X, Tian R (2018) Seasonal hydrochemical characterization and groundwater quality delineation based on matter element extension analysis in a paper wastewater irrigation area. Northwest China Expo Health 10:241-258. https://doi.org/10.1007/ s12403-017-0258-6

Li P, Tian R, Liu R (2019) Solute geochemistry and multivariate analysis of water quality in the Guohua Phosphorite Mine, Guizhou Province. China Expo Health 11(2):81-94. https://doi.org/10. 1007/s12403-018-0277-y

Loh YSA, Akurugu BA, Manu E, Aliou AS (2020) Assessment of groundwater quality and the main controls on its hydrochemistry in some Voltaian and basement aquifers, northern Ghana. Groundw Sustain Dev 10:100296. https://doi.org/10.1016/j.gsd. 2019.100296

Lu W, Arias Font R, Cheng S, Wang J, Kollmann J (2019) Assessing the context and ecological effects of river restoration-a metaanalysis. Ecol Eng 136:30-37. https://doi.org/10.1016/j.ecoleng. 2019.06.004

Mishra S, Kumar A (2020) Estimation of physicochemical characteristics and associated metal contamination risk in the Narmada River, India. Environ Eng Res 26(1):1. https://doi.org/10.4491/ eer.2019.521

Mitsch WJ (2014) Unifying a city with its natural riverine environment for the benefit of both: extending Ohio's only wetland of international importance to a much larger river ecosystem corridor. Ecol Eng 72:138-142. https://doi.org/10.1016/j.ecoleng.2014.09.104

Prakash K, Singh S, Mohanty T, Chaubey K, Singh CK (2017) Morphometric assessment of Gomati river basin, middle Ganga plain, Uttar Pradesh, North India. Spat Inf Res 25:449-458. https://doi. org/10.1007/s41324-017-0110-x

Ren X, Li P, He X, Su F, Elumalai V (2021) Hydrogeochemical processes affecting groundwater chemistry in the central part of the Guanzhong Basin. China Arch Environ Contam Toxicol 80:74 91. https://doi.org/10.1007/s00244-020-00772-5

Sharan A (2016) A river and the riverfront: Delhi's Yamuna as an in-between space. City. Cult Soc 7:267-273. https://doi.org/10. 1016/j.ccs.2014.12.001

Shukla S, Khan R, Hussain CM (2020) Chapter 16. Nanoremediation. In: The handbook of environmental remediation. Royal Society of Chemistry, pp 443-467. https://doi.org/10.1039/9781788016 261-00443

Shukla S, Saxena A (2020a) Groundwater quality and associated human health risk assessment in parts of Raebareli district, Uttar Pradesh, India. Groundw Sustain Dev 10:100366. https://doi.org/ 10.1016/j.gsd.2020.100366
Shukla S, Saxena A (2020b) Appraisal of groundwater quality with human health risk assessment in parts of indo-gangetic Alluvial Plain, North India. Arch Environ Contam Toxicol 80:55-73. https://doi.org/10.1007/s00244-020-00771-6

Shukla S, Saxena A (2020c) Water quality index assessment of groundwater in the Central Ganga Plain with reference to Raebareli district, Uttar Pradesh. India Curr Sci 119:1308-1315. https://doi. org/10.18520/cs/v119/i8/1308-1315

Shukla S, Saxena A (2020d) Sources and leaching of nitrate contamination in groundwater. Curr Sci 118:883-891. https://doi.org/10. $18520 / \mathrm{cs} / \mathrm{v} 118 / \mathrm{i} 6 / 883-891$

Su F, Wu J, He S (2019) Set pair analysis-Markov chain model for groundwater quality assessment and prediction: a case study of Xi' an City. China Hum Ecol Risk Assess 25(1-2):158-175. https://doi.org/10.1080/10807039.2019.1568860

Su F, Li P, He X, Elumalai V (2020) Set pair analysis in earth and environmental sciences: development, challenges, and future prospects. Expo Health 12(3):343-354. https://doi.org/10.1007/ s12403-020-00368-3

Tangri AK, Kumar D, Singh DS, Dubey CA (2018) The Gomati River: lifeline of central Ganga plain. Springer, Singapore, pp 135-150. https://doi.org/10.1007/978-981-10-2984-4_11

Thompson J, Pelc CE, Brogan WR, Jordan TE (2018) The multiscale effects of stream restoration on water quality. Ecol Eng 124:7-18. https://doi.org/10.1016/j.ecoleng.2018.09.016

Tian R, Wu J (2019) Groundwater quality appraisal by improved set pair analysis with game theory weightage and health risk estimation of contaminants for Xuecha drinking water source in a loess area in northwest China. Hum Ecol Risk Assess 25(1-2):132-157. https://doi.org/10.1080/10807039.2019.1573035

Vaughan IP, Ormerod SJ (2010) Linking ecological and hydromorphological data: approaches, challenges and future prospects for riverine science. Aquat Conserv Mar Freshw Ecosyst 20(1):S125S130. https://doi.org/10.1002/aqc.1104

Woldeab B, Beyene A, Ambelu A, Buffam I, Mereta ST (2018) Seasonal and spatial variation of reservoir water quality in the southwest of Ethiopia. Environ Monit Assess 190:1-13. https://doi.org/ 10.1007/s10661-018-6527-4

Wu J, Li P, Qian H, Duan Z, Zhang X (2014) Using correlation and multivariate statistical analysis to identify hydrogeochemical processes affecting the major ion chemistry of waters: Case study in Laoheba phosphorite mine in Sichuan. China Arab J Geosci 7(10):3973-3982. https://doi.org/10.1007/s12517-013-1057-4

Wu J, Li P, Wang D, Ren X, Wei M (2020) Statistical and multivariate statistical techniques to trace the sources and affecting factors of groundwater pollution in a rapidly growing city on the Chinese Loess Plateau. Hum Ecol Risk Assess 26:1603-1621. https://doi. org/10.1080/10807039.2019.1594156

Wu Z, Zhang D, Cai Y, Wang X, Zhang L, Chen Y (2017) Water quality assessment based on the water quality index method in Lake Poyang: the largest freshwater lake in China. Sci Rep 7:17999. https://doi.org/10.1038/s41598-017-18285-y

Zhu B, Wang X, Rioual P (2017) Multivariate indications between environment and ground water recharge in a sedimentary drainage basin in northwestern China. J Hydrol 549:92-113. https://doi.org/ 10.1016/j.jhydrol.2017.03.058

Publisher's Note Springer Nature remains neutral with regard to jurisdictional claims in published maps and institutional affiliations. 


\section{Authors and Affiliations}

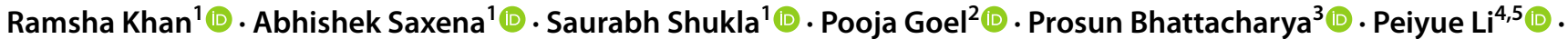 Esmat F. Ali ${ }^{6}$. Sabry M. Shaheen ${ }^{7,8,9}$}

Ramsha Khan

ramshaokhan@gmail.com

Pooja Goel

goelpooja78@rediffmail.com

Prosun Bhattacharya

prosun@kth.se

Peiyue Li

lipy2@163.com; peiyueli@chd.edu.cn

Esmat F. Ali

a.esmat@tu.edu.sa

1 Faculty of Civil Engineering, Institute of Technology, Shri Ramswaroop Memorial University, Barabanki, UP 225003, India

2 Centre of Advanced Study in Geology, University of Lucknow, Lucknow 226 007, India

3 KTH-International Groundwater Arsenic Research Group, Department of Sustainable Development, Environmental Science and Engineering, KTH Royal Institute of Technology, Teknikringen 10B, 10044 Stockholm, Sweden
4 School of Water and Environment, Chang'an University, No. 126 Yanta Road, Xi'an 710054, Shaanxi, China

5 Key Laboratory of Subsurface Hydrology and Ecological Effects in Arid Region of the Ministry of Education, Chang'an University, No. 126 Yanta Road, Xi'an 710054, Shaanxi, China

6 Department of Biology, College of Science, Taif University, P.O. Box 11099, Taif 21944, Saudi Arabia

7 School of Architecture and Civil Engineering, Institute of Foundation Engineering, Water- and Waste-Management, Laboratory of Soil-and Groundwater-Management, University of Wuppertal, Pauluskirchstraße 7, 42285 Wuppertal, Germany

8 Faculty of Meteorology, Environment, and Arid Land Agriculture, Department of Arid Land Agriculture, King Abdulaziz University, Jeddah 21589, Saudi Arabia

9 Faculty of Agriculture, Department of Soil and Water Sciences, University of Kafrelsheikh, 33 516, Kafr El-Sheikh, Egypt 